\title{
Modulation of Wnt/ $\beta$-catenin signaling affects the directional differentiation of hair follicle stem cells
}

\author{
Bin Yang, Xiao-Ying Wu, Jian Ni, Bing-Hang Li, Li-Huan Deng, Meng-Juan Xiang \\ Plastic Surgery Hospital and Institute, Chinese Academy of Medical Sciences, Peking Union Medical College, Shijingshan, Beijing 100144,
} China

Address for correspondence: Prof. Bin Yang, Plastic Surgery Hospital and Institute, Chinese Academy of Medical Sciences, Peking Union Medical College, Shijingshan, Beijing 100144, China. E-mail: ybdoctor_psh@163.com.

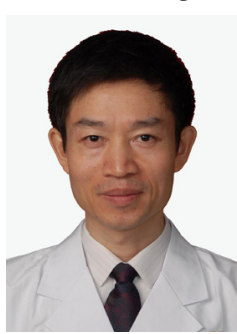
Prof. Bin Yang has engaged himself in practicing and researching cranio-maxillo-facial surgery for thirty years. He undertook successively more than
ten scientific projects, including national and provincial priority projects supported by government fund. He possess national patent for invention of
the head fixing frame for CT scanner. The project of surgical treatment of craniofacial malformations was awarded National and Provincial Scientific
$\&$ Technological Advance Prize respectively in 1995 and 2008 . He had published seven monographs, among two of those books he served as the
editor-in-chief. He have had approximate 70 original articles, reviews and translations published on journals. He has 30 -years experiences in treating
craniomaxillofacial malformation. He has performed a lot of major surgical procedures on craniofacial deformities and gotten satisfactory results.
Especially he used the distraction technique to treat Treacher-Collins syndrome, hemifacial microsomia, etc., having gotten both good appearance and
physiologic function. His practice scope include craniomaxillofacial deformities, especially congenital craniofacial malformation, such as Crouzon
syndrome and craniosynostosis (scaphocephalies, turricephalies, brachycephalies, plagiocephalies, triangucephalies), orthognathic surgery, cleft lip and
palate, scalp and skull defect, orbital hypertelorism, etc. ABSTRACT

Aim: The differentiation of hair follicle stem cells (HFSCs) into hair follicle cells has potential clinical applications for cutaneous burns. However, the mechanisms regulating the differentiation of HFSCs into hair follicular papilla or epidermal cells are currently not clear. This study investigated the role of the Wnt $/ \beta$-catenin pathway and its crosstalk with other signaling components during this differentiation process. Methods: Lithium chloride $(\mathrm{LiCl}, 10 \mathrm{mmol} / \mathrm{L})$ and keratinocyte growth factor $(\mathrm{KGF}, 10 \mu \mathrm{g} / \mathrm{L})$ were used to induce HFSC differentiation, validated by immunofluorescence analysis. The mRNA expression of $\beta$-catenin, adenomatous polyposis coli, glycogen synthase kinase-3 $\beta$ (GSK-3 $\beta$ ), axin, and lymphoid enhancer factor- 1 after 3, 5, 7, and 9 days were measured to evaluate the role of the Wnt/ $\beta$ catenin pathway. Results: During LiCl-induced HFSC differentiation into hair follicle cells, the Wnt/ $\beta$-catenin signaling pathway was activated and the expression of GSK-3 $\beta$, a vital component of the degradation compound, was inhibited. This led to increased cytoplasmic $\beta$-catenin expression, nuclear translocation, and subsequent target gene transcription. By contrast, KGF induced the differentiation of HFSCs into epidermal cells and did not affect the expression of $\beta$-catenin. This data indicates that $\mathrm{LiCl}$ and KGF distinctly regulate the differentiation of HFSCs into hair follicle and epidermal cells, respectively. Furthermore, the Wnt/ $\beta$-catenin signaling pathway is predominantly involved in hair follicle differentiation. Conclusion: these results demonstrate that $\mathrm{LiCl}$ can be used to differentiate HFSCs into hair follicle cells in vitro, which has important therapeutic applications for treating patients with cutaneous damage.

Key words:

Lithium chloride; keratinocyte growth factor; hair follicle stem cells; Wnt/ $\beta$-catenin signaling pathway

\begin{tabular}{|l|l|}
\hline \multicolumn{2}{|c|}{ Access this article online } \\
\hline Quick Response Code: & Website: \\
\hline & www.parjournal.net \\
\cline { 2 - 3 } & \\
\cline { 2 - 3 } & \\
\hline
\end{tabular}

This is an open access article distributed under the terms of the Creative Commons Attribution-NonCommercial-ShareAlike 3.0 License, which allows others to remix tweak and build upon the work non-commercially, as long as the author is credited and the new creations are licensed under the identical terms.

For reprints contact: service@oaepublish.com

How to cite this article: Yang B, Wu XY, Ni J, Li BH, Deng LH, Xiang MJ. Modulation of $W n t / \beta$-catenin signaling affects the directional differentiation of hair follicle stem cells. Plast Aesthet Res 2016;3:39-46.

Received: 04-07-2015; Accepted: 18-12-2015 


\section{INTRODUCTION}

The discovery of hair follicle stem cells (HFSCs) and the development of methods to culture these cells in vitro have led to the possibility of developing new tissue engineering treatments for cutaneous damage caused by burns. ${ }^{[1]}$ HFSCs are highly proliferative multipotent stem cells with multi-lineage potential. They can differentiate into a range of distinct cell types including epidermal cells, hair follicle cells, and sebaceous cells. ${ }^{[2]}$ Both the proliferation rate and the differentiation capacity of HFSCs are influenced by autologous genes and external signals. The $\mathrm{Wnt} / \beta$-catenin signaling pathway plays a crucial role in the development of follicles and hair. ${ }^{[3,4]}$ During both embryonic development and tumorigenesis Wnt proteins bind to their receptors and activate $\mathrm{Wnt} / \beta$ catenin signaling, leading to $\beta$-catenin accumulation in the cytoplasm and subsequent nuclear translocation. $\beta$-catenin binding to lymphoid enhancer factor-1 (LEF1) activates target genes and accelerates the directional differentiation of HFSCs. ${ }^{[3,4]}$ Other factors, including chemicals (e.g. LiCl) and growth factors, influence cytoplasmic $\beta$-catenin levels in HFSCs, leading to HFSC differentiation. ${ }^{[1]}$ However, details of the mechanism require further investigation. The purpose of this study was to investigate how keratinocyte growth factor (KGF) and $\mathrm{LiCl}$ influence the function of the $\mathrm{Wnt} / \beta$-catenin signaling pathway and its interaction with other signaling components during human HFSC differentiation into dermal papilla and epidermal cells.

\section{METHODS}

\section{Tissue harvest and cell isolation}

Fresh scalp specimens were obtained under aseptic condition and HFSCs were isolated using previously established methods. ${ }^{[1]}$ Briefly, scalp skin from patients undergoing surgery was washed repeatedly with phosphate buffered solution (PBS) containing 5\% penicillin and streptomycin (North China Pharmaceutical Corporation, China). After removing subcutaneous adipose tissue and impurities, the skin was cut into $4 \mathrm{~mm} \times 2 \mathrm{~mm}$ pieces, placed in a centrifuge tube containing $0.25 \%$ Dispase (Shanghai Biological Technical Company, China), and digested overnight at $4{ }^{\circ} \mathrm{C}$. The hair follicles were then gently pulled out in the direction of hair growth. The dissociated adipose tissue was then washed with PBS and hair follicles were added to a $60-\mathrm{mm}$ petri dish containing 10\% fetal bovine serum (FBS) in Dulbecco's Modified Eagle Media (DMEM; Hyclone, USA). Bulge areas were isolated from the hair follicles by incubation with 2.5 $\mathrm{g} / \mathrm{L}$ trypsin and $0.04 \%$ EDTA for $10 \mathrm{~min}$ at $37^{\circ} \mathrm{C}$, followed by centrifugation and resuspension in K-SFM medium (Shanghai Biological Technical Company, Shanghai, China) at a density of $5 \times 10^{7}$ cells/L. Cells were incubated at $37^{\circ} \mathrm{C}$ under $5 \% \mathrm{CO}_{2}$ in a humidified incubator. The culture medium was replaced every 3-4 days, and HFSCs were cultured and passaged three times prior to being used for all experiments.

\section{Measuring the proliferation rate of HFSCs}

To measure their rates of proliferation, HFSCs were seeded at the following four different densities: $1 \times 10^{3}, 1 \times 10^{4}, 1 \times 10^{5}$, and $1 \times 10^{6}$ cells $/ \mathrm{mL}$ of 24 -well plate. Growth curves of the HFSCs were obtained by seeding $1 \times 10^{5}$ logarithmically growing cells in $1 \mathrm{~mL}$ medium into each well of a 24 -well culture plate. A total of 36 wells were used. Hoechst 33258 DNA quantitation was performed every day after 7 days in culture.

\section{Immunofluorescence assay}

Immunofluorescence analysis was performed as previously described. ${ }^{[5]}$ Briefly, sterile glass coverslips were placed into $60 \mathrm{~mm}$ dishes, and approximately $2 \times 10^{4}$ cells $/ \mathrm{mL}$ of 24 -well plate were seeded into each dish. After 7 days in culture, adherent cells were stained for pan-cytokeratin, K19-Cy3, and $\beta 1$-integrin and analyzed by immunofluorescence microscopy.

\section{Treatment with $\mathrm{LiCl}$ and KGF}

To investigate the effects of specific compounds on HFSC differentiation, HFSCs were treated with $\operatorname{LiCl}(0.5,1.5,10$, or $25 \mathrm{mmol} / \mathrm{L})$ or $\operatorname{KGF}(10,25,50$, or $100 \mu \mathrm{g} / \mathrm{L})$. After 7 days, Hoechst 33258 DNA quantitation was performed to compare

Table 1: Primer sequences and amplified fragments

\begin{tabular}{|c|c|c|c|}
\hline Primer pairs & Sequences (5' to $\left.3^{\prime}\right)$ & $\begin{array}{l}\text { Denaturation temperature } \\
\left({ }^{\circ} \mathrm{C}\right)\end{array}$ & Fragment size (bp) \\
\hline $\begin{array}{l}\beta \text {-catenin forward } \\
\beta \text {-catenin reverse }\end{array}$ & $\begin{array}{l}\text { TACCTCCCAAGTCCTGTATGAG } \\
\text { TGAGCAGCATCAAACTGTGTAG }\end{array}$ & 56.0 & 180 \\
\hline $\begin{array}{l}\text { APC forward } \\
\text { APC reverse }\end{array}$ & $\begin{array}{l}\text { TTAAAGCAAGTTGAGGCACTG } \\
\text { ACCGGCTTCCATAAGAACGGA }\end{array}$ & 55.5 & 270 \\
\hline $\begin{array}{l}\text { Axin forward } \\
\text { Axin reverse }\end{array}$ & $\begin{array}{l}\text { GCGGGACAGATTGATTCACTT } \\
\text { TGTGGACACCAGTTCTCCCT }\end{array}$ & 57.0 & 190 \\
\hline $\begin{array}{l}\text { GSK- } 3 \beta \text { forward } \\
\text { GSK-3 } \beta \text { reverse }\end{array}$ & $\begin{array}{l}\text { ATTTCCAGGGGATAGTGGTGT } \\
\text { TCCTGACGAATCCTTAGTCCAAG }\end{array}$ & 56.0 & 154 \\
\hline $\begin{array}{l}\text { LEF1 forward } \\
\text { LEF1 reverse }\end{array}$ & $\begin{array}{l}\text { AATGAGAGCGAATGTCGTTGC } \\
\text { GCTGTCTTTCTTTCCGTGCTA }\end{array}$ & 56.5 & 137 \\
\hline $\begin{array}{l}\text { GAPDH forward } \\
\text { GAPDH reverse }\end{array}$ & $\begin{array}{l}\text { TGTTGCCATCAATGACCCCTT } \\
\text { CTCCACGACGTACTCAGCG }\end{array}$ & 57.0 & 202 \\
\hline
\end{tabular}

APC: adenomatous polyposis coli; GSK-3ß: glycogen synthase kinase-3ß; LEFI: lymphoid enhancer factor-I; GAPDH: glyceraldehyde-3-phospha 

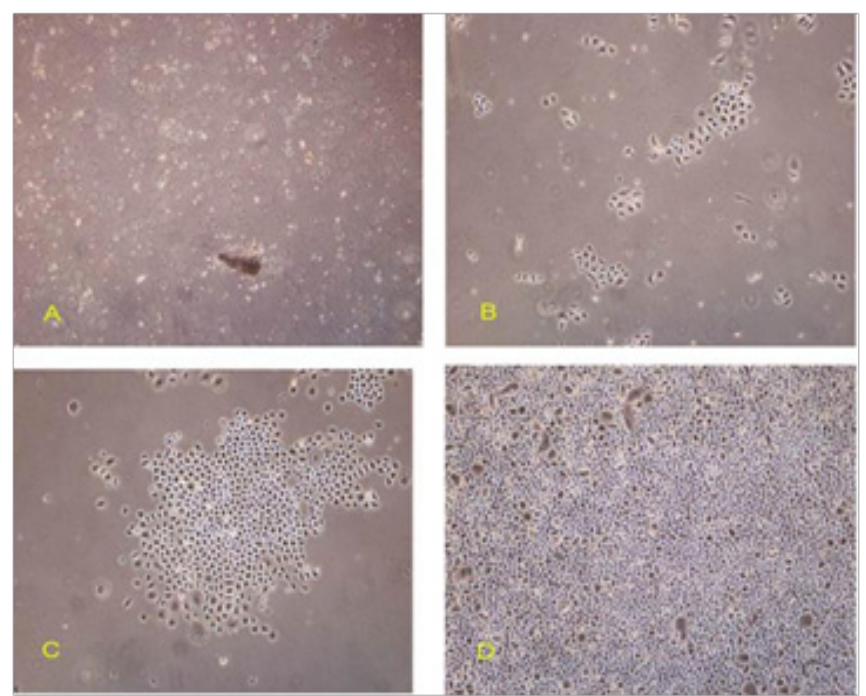

Figure 1: Primary culture of hair follicle stem cells (HFSCs). (A) Partial adherence of HFSCs ( $\mathrm{PO}, 1$ day); (B) adherent cell growth ( $\mathrm{PO}, 3$ days); (C) logarithmic cell growth (P0, 7 days); (D) cells reached 100\% confluency (P0, 9 days). Magnification, $\times 40$

the effects of different incubation times on cell proliferation.

\section{Reverse transcriptase-polymerase chain reaction analysis of mRNA expression}

The reverse transcriptase-polymerase chain reaction (RT$P C R)^{[6,7]}$ was used to measure the expression of $\beta$-catenin, adenomatous polyposis coli (APC), axin, glycogen synthase

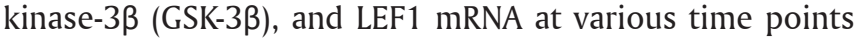
following treatment with $10 \mathrm{mmol} / \mathrm{L} \mathrm{LiCl}$. HFSCs were resuspended in K-SFM medium (without fetal calf serum) and seeded into a $100-\mathrm{mm}$ culture dish at a concentration of $1 \times 10^{5}$ cells $/ \mathrm{mL}$. LiCl was then added to the medium at a concentration of $10 \mathrm{mmol} / \mathrm{L}$. RT-PCR was used to measure the expression of $\beta$-catenin, APC, axin, GSK-3 $\beta$, and LEF1 mRNA after 3, 5, 7, and 9 days in culture. An untreated group was included as a control. Similarly, following treatment with KGF, $\beta$-catenin, APC, axin, GSK-3 $\beta$, and LEF1 mRNA expression was measured on days $3,5,7$, and 9. An untreated control group was included.

Isolation of total RNA: total RNA was isolated with TRIZOL using Superscript III (Invitrogen, CA, USA), according to the manufacturer's protocol.

Reverse transcription: template RNA $(1 \mu \mathrm{g})$ and $1 \mu \mathrm{g}$ Oligo (dT) 15 were added to RNase-free water (to a final volume of $5 \mu \mathrm{L})$. After mixing well, the reaction was incubated at $70{ }^{\circ} \mathrm{C}$ for $5 \mathrm{~min}$, chilled on ice for $5 \mathrm{~min}$, and then $13.5 \mu \mathrm{L}$ RNasefree water, $4 \mu \mathrm{L} 5 \times$ RT Buffer, $1 \mu \mathrm{L}$ dNTPs, $1 \mu \mathrm{L}$ RNAase inhibitor and $1 \mu \mathrm{L}$ MMLV RNase were added. The reaction was incubated at $36^{\circ} \mathrm{C}$ for $10 \mathrm{~min}, 42^{\circ} \mathrm{C}$ for $60 \mathrm{~min}$, and then inactivated at $70{ }^{\circ} \mathrm{C}$ for $10 \mathrm{~min}$, cooled on ice, and stored.

Primer design and synthesis: primer design was based on the target DNA sequences. To avoid contamination of genomic DNA, primer pairs were designed to amplify across an intron [Table 1]. Primers were synthesized by Shanghai Sango Biotech Co. Ltd. (Shanghai, China).

RT-PCR reagents: RT-PCR reagents contained $1 \mu \mathrm{L}$ template

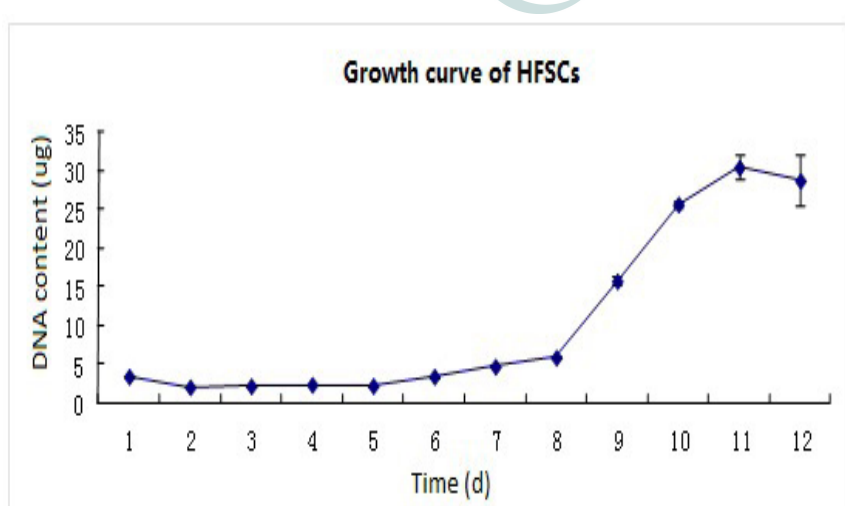

Figure 2: Growth curves of primary culture cells from scalp follicular bulge. HFSCs: hair follicle stem cells.

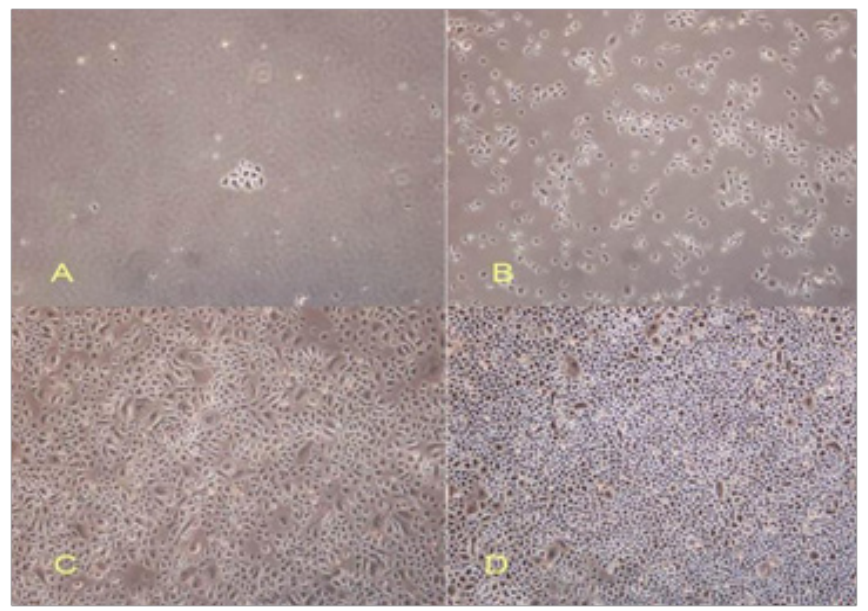

Figure 3: The effect of seeding density on cell growth. Cells were seeded at densities of $1 \times 10^{3}$ cells $/ \mathrm{mL}(\mathrm{A}), 1 \times 10^{4}$ cells $/ \mathrm{mL}(\mathrm{B}), 1 \times 10^{5}$ cells $/ \mathrm{mL}$ (C), or $1 \times 10^{6}$ cells $/ \mathrm{mL}$ (D). Cell proliferation and cells morphology were assessed after 3 days in subculture. Magnification, $\times 40$.

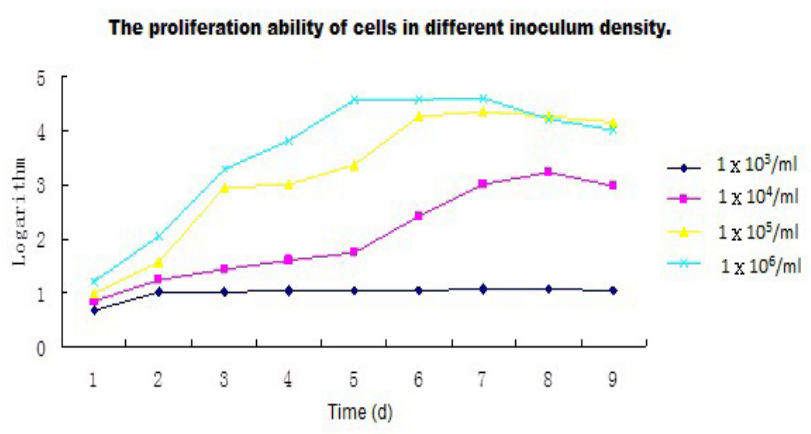

Figure 4: Proliferation of primary culture cells at different seeding densities

RNA, $1.5 \mu \mathrm{L}$ of $25 \mathrm{mmol} / \mathrm{L} \mathrm{MgC12,4} \mu \mathrm{L} 5 \times$ PCR buffer, 1 $\mu \mathrm{L}$ dNTPs, I $\mu \mathrm{L}$ each primer, $0.5 \mu \mathrm{L}$ Taq DNA polymerase, and $9.5 \mu \mathrm{L}$ RNase-free water. RT-PCR were subjected to an initial denaturation for $3 \mathrm{~min}$ at $94{ }^{\circ} \mathrm{C}$, and then 35 cycles of $94{ }^{\circ} \mathrm{C}$ for $45 \mathrm{~s}, 56{ }^{\circ} \mathrm{C}$ for $30 \mathrm{~s}$, and $72{ }^{\circ} \mathrm{C}$ for $1 \mathrm{~min}$. A final extension for $5 \mathrm{~min}$ at $72{ }^{\circ} \mathrm{C}$ was performed before the reaction was stored at $4{ }^{\circ} \mathrm{C}$. Reaction products were analyzed by electrophoresis. Primers and annealing temperatures are shown in Table 1.

\section{Statistical analysis}

All data were analyzed using SPSS10.0. Statistical significance 

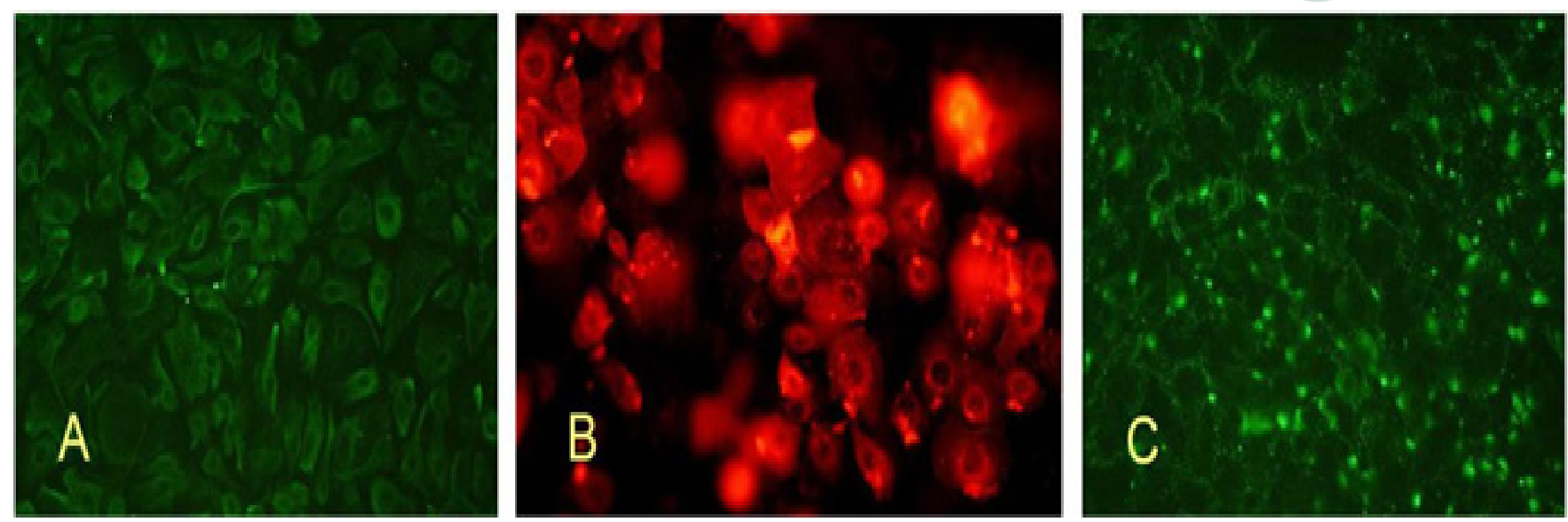

Figure 5: Hair follicle stem cells morphological observation and protein expression. Cells have round or oval nuclei and a high nucleus and cytoplasm ratio. Immunofluorescence staining of pan-cytokeratin (A), K19 (B), and $\beta 1$-integrin (C). Magnification, $\times 200$
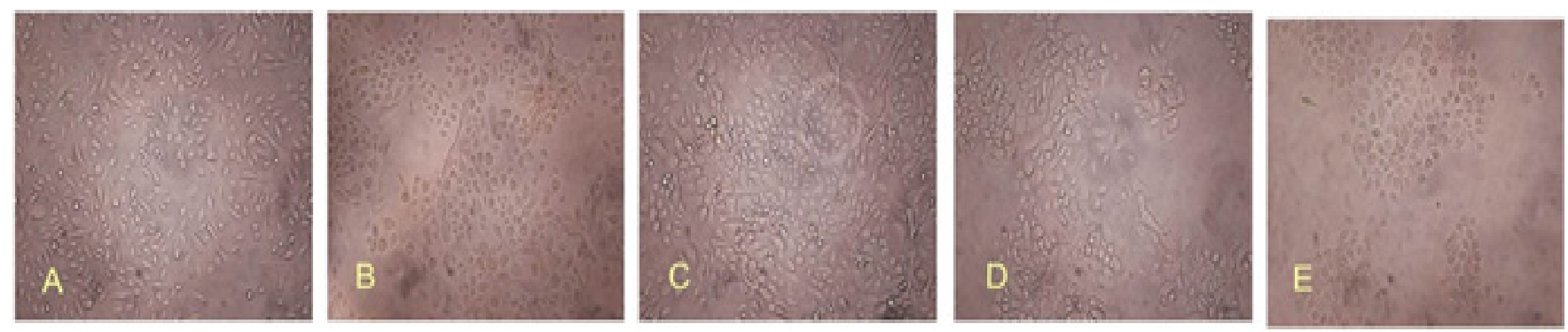

Figure 6: Effect of different $\mathrm{LiCl}$ concentrations on hair follicle stem cells proliferation. Cells were assessed 3 days after treatment of LiCl at different concentrations. (A) after treatment with $0 \mathrm{mmol} / \mathrm{L} \mathrm{LiCl}$, cells have grown well and display a cobblestone-like appearance; (B) after treatment with $0.5 \mathrm{mmol} /$ $\mathrm{L} \mathrm{LiCl}$, cells have become rounded, or occasionally an elongated spindle shape, and show a tendency to aggregate; (C) after treatment with $1.5 \mathrm{mmol} / \mathrm{L}$ LiCl, in general, cells have become larger. Occasionally, cells have developed protuberances, which may be related to cell migration; (D) after treatment with $10 \mathrm{mmol} / \mathrm{L} \mathrm{LiCl}$, cell morphology has changed. Cells have become highly aggregated and cell density is reduced; (E) after treatment with $25 \mathrm{mmol} / \mathrm{L} \mathrm{LiCl,}$ cell density has significantly decreased. Both the cytoplasm and nuclei show various morphological changes. The proliferation rate has also decreased. Magnification, $\times 100$

was set at $P<0.05 ; P<0.01$ indicates that the difference between experimental groups was significant; $P>0.05$ indicates no difference between experimental groups.

\section{RESULTS}

\section{HFSC growth characteristics}

Primary cells derived from the hair follicle bulge were spheroid, small, and evenly sized. Live cells were optically transparent with a clear boundary and clusters of undissociated cells could be seen [Figure 1]. Trypan blue staining showed that $95 \%$ of cells were alive. At the initial stage of culture, cell adhesion and activity were weak. After culture in serum-free K-SFM containing epidermal growth factor (EGF) for 1-3 days, a few human HFSCs were observed to adhere

\section{Effect of LiCl on HFSCs proliferation}

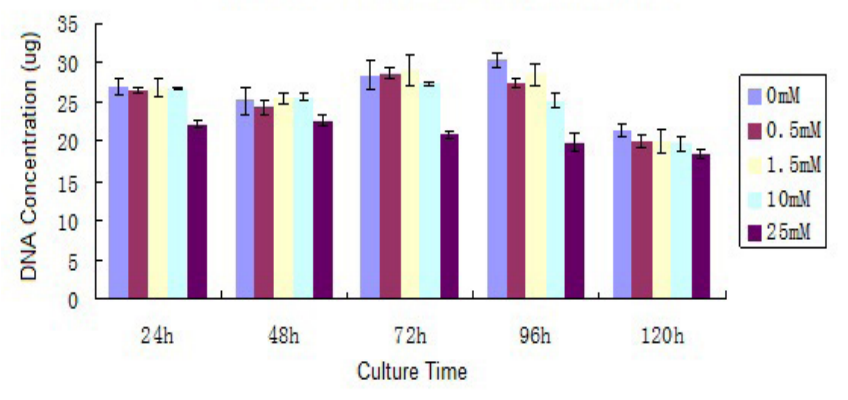

Figure 7: Effect of $\mathrm{LiCl}$ on hair follicle stem cells (HFSCs) proliferation to culture vessel, although most remained in suspension [Figure $1 \mathrm{~A}$ and $\mathrm{B}$ ]. After 4-6 days in culture, a few single cells or cell clusters had attached to the culture dish; these had a cobblestone-like appearance, an orderly arrangement, and were highly refractive. Cell numbers increased with increasing culture time [Figure 1C and D]. After 2 weeks in culture, a small number of aging cells were observed.

\section{Dynamics of cell growth}

Growth curves [Figures 1 and 2] show that the cell growth rate was slow on days 1-3. On days 4-6, cells grew faster and were in the logarithmic phase. After this point, cell growth became slower and aging cells appeared.

Cell proliferation varied according to seeding density [Figures 3 and 4]. At seeding densities of $1 \times 10^{3}$ and $1 \times 10^{4}$, a few cells showed clonal growth but cells proliferated slowly and most died after a short time in culture. When the seeding density was increased to $1 \times 10^{5}$ cells $/ \mathrm{mL}$, cells proliferated well and showed adherent growth at early time points. Cells seeded at a density of $1 \times 10^{6}$ cells/mL rapidly formed clusters and underwent contact inhibition following rapid nutrient depletion. These cells showed signs of aging.

\section{Identification of HFSCs and characteristics of HFSC protein expression}

Pan-cytokeratin expression: adherent pan-cytokeratinlabeled HFSCs showed that the cytoplasm of these cells 

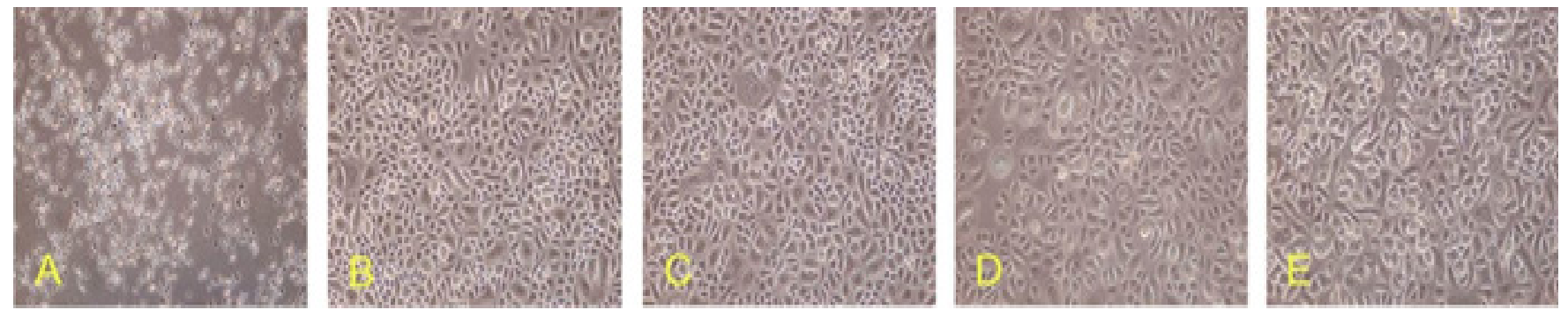

Figure 8: Effect of different keratinocyte growth factor (KGF) concentrations on hair follicle stem cells proliferation. Cells were assessed 3 days after treatment. (A) the KGF $0 \mu \mathrm{g} / \mathrm{L}$ group shows cells have grown well and display a cobblestone-like appearance; (B) the KGF $10 \mu \mathrm{g} / \mathrm{L}$ group shows cell density has increased. A small number of enlarged cells have appeared; (C) the KGF $25 \mu \mathrm{g} / \mathrm{L}$ group shows differentiated cells with enlarged nuclei and enriched cytoplasm can be seen; (D) the KGF $50 \mu \mathrm{g} / \mathrm{L}$ group shows the proportion of differentiated cells increased, and the cell density decreased; (E) the KGF 100 $\mu \mathrm{g} / \mathrm{L}$ group shows the proportion of differentiated cells increased, cell aging was observed. Magnification, $\times 100$.

Effect of KGF on HFSCs proliferation

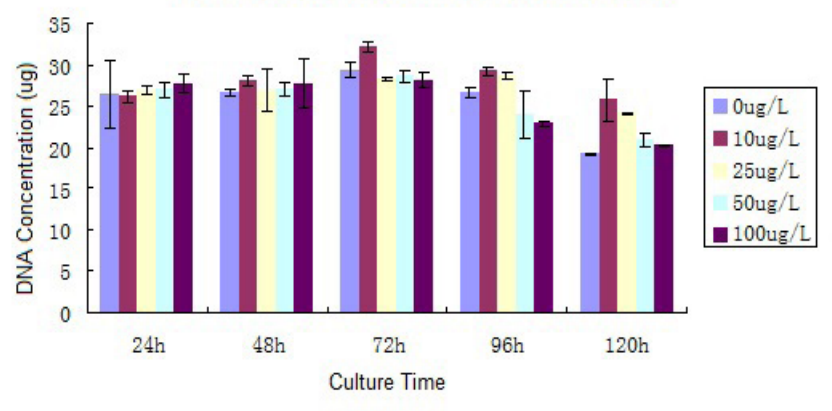

Figure 9: Effect of keratinocyte growth factor (KGF) on hair follicle stem cells (HFSCs) proliferation

were positive for pan-cytokeratin [Figure 5A]. Cytokeratin is a defining feature of HFSCs..$^{[5,8]}$

K19-Cy3 expression: isolated keratin 19 (K19)-labeled HFSC clusters were positive for cytoplasmic K19 [Figure 5B]. K19 is a specific cytoplasmic marker for HFSCs. ${ }^{[5,9]}$

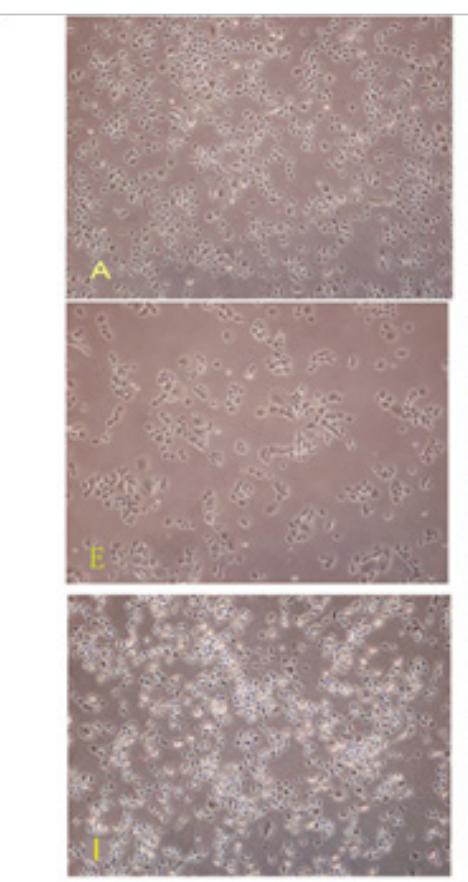

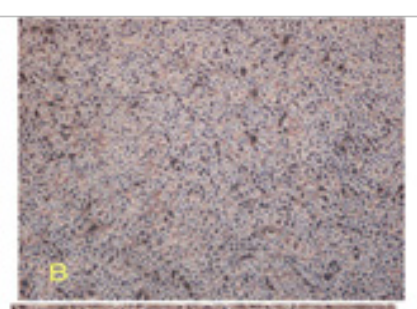
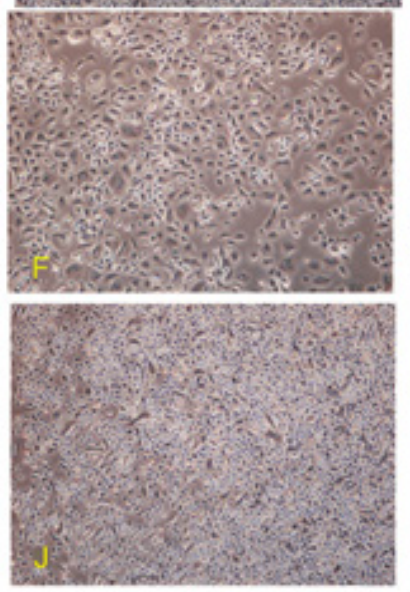

$\beta 1$-integrin expression: $\mathrm{HFSCs}$ showed a high rate of $\beta 1$-integrin expression, as shown in Figure 5C. Positively stained cells grew in clusters. Previous studies have confirmed that $\beta 1$ integrin is a membrane marker for HFSCs. $.5,8]$

The influence of $\mathrm{LiCl}$ on HFSC proliferation There were no significant differences between the proliferation rates of HFSCs treated with lower doses of $\mathrm{LiCl}$ and that of the control group; there was an inverse correlation between dose and proliferation rate at higher concentrations of LiCl than $10 \mathrm{mmol} / \mathrm{L}$ [Figures 6 and 7]. $\mathrm{LiCl}$ concentrations less than $10 \mathrm{mmol} / \mathrm{L}$ had no effect on the proliferation rate; moreover, treatment with $0-10 \mathrm{mmol} / \mathrm{L}$ LiCl did not markedly affect cell proliferation, especially for culture times greater than $72 \mathrm{~h}(P>0.05)$. However, the proliferation rate decreased at a $\mathrm{LiCl}$ concentration of 25 $\mathrm{mmol} / \mathrm{L}$; there was a clear difference between treated and control cells at each time point $(P<0.05)$.

After $24 \mathrm{~h}$ of culture, DNA quantitation in the $25 \mathrm{mmol} / \mathrm{L}$ group compared with $0 \mathrm{mmol} / \mathrm{L}$ group, $P<0.05$, as compared with other groups, $P>0.05$; after $48 \mathrm{~h}$ of

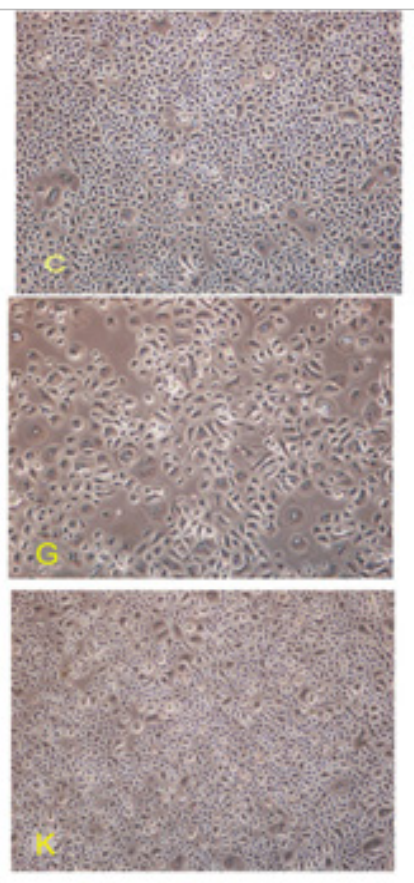

Figure 10: Untreated hair follicle stem cells (HFSCs). Cells morphological features of negative controls (HFSCs subculturing without intervention) after 3 (A), 5 (B), 7 (C), and 9 (D) days in culture. HFSC treated with $10 \mathrm{mmol} / \mathrm{L} \mathrm{LiCl}$. Cells morphological features shown after 3 (E), 5 (F), 7 (G), and 9 (H) days in culture. HFSCs treated with $10 \mu \mathrm{g} / \mathrm{L} \mathrm{KGF}$. Cells morphological features shown after 3 (I), 5 (J), 7 (K), and 9 (L) days in culture. Magnification, $\times 40$. 

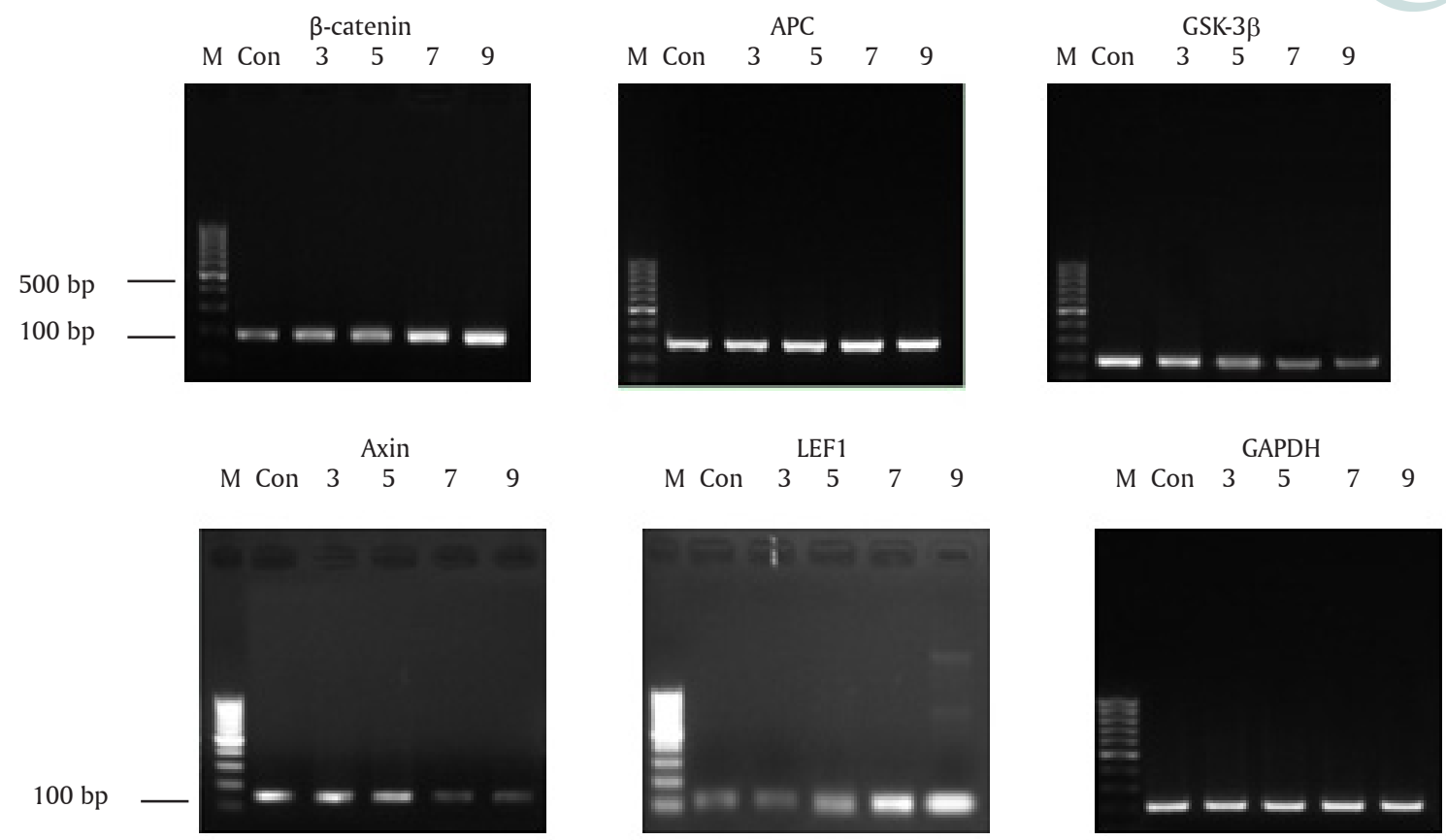

Figure 11: Effect of $10 \mathrm{mmol} / \mathrm{L} \mathrm{LiCl}$ on $\beta$-catenin, APC, GSK-3 $\beta$, axin, and LEF1 mRNA expression. APC: adenomatous polyposis coli; GSK-3: glycogen synthase kinase-3ß; LEF1: lymphoid enhancer factor-1.

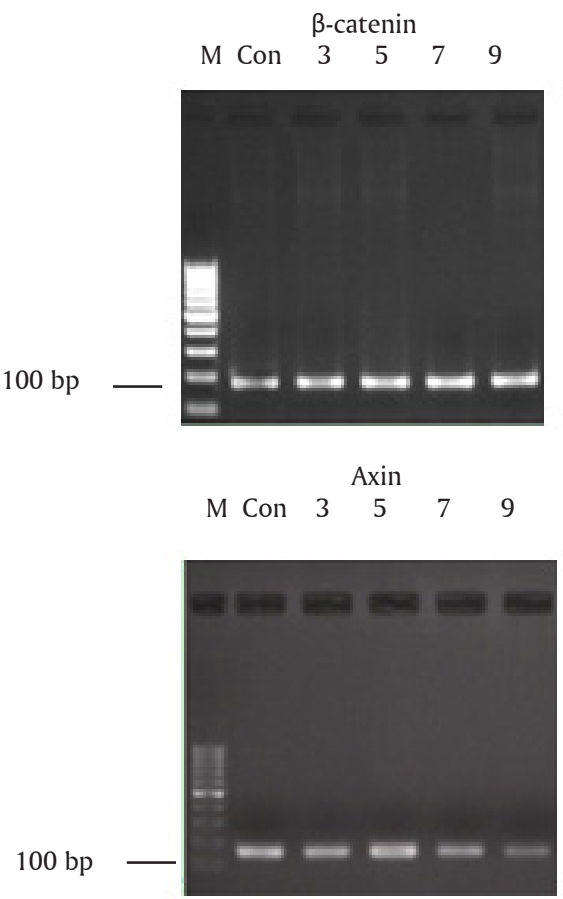

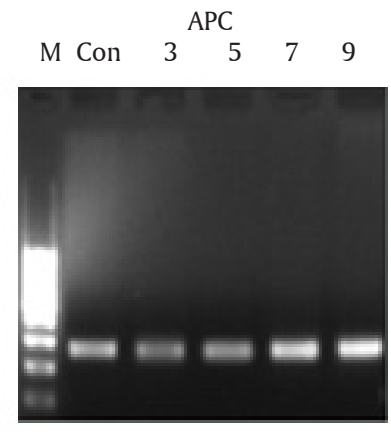
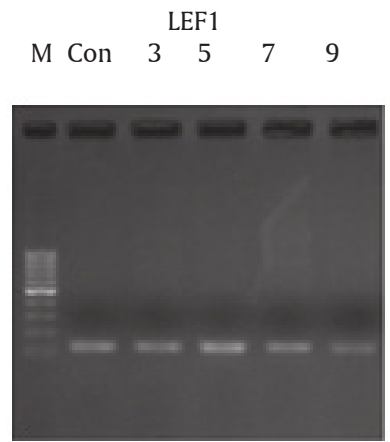
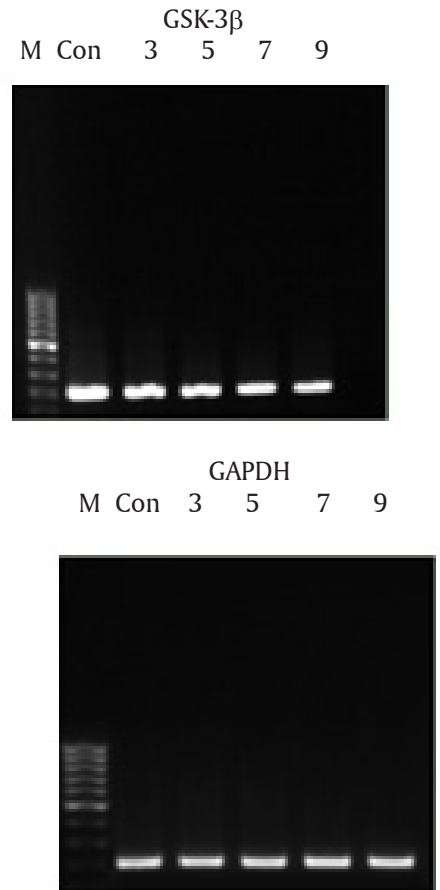

Figure 12: Effect of $10 \mu \mathrm{g} / \mathrm{L} \mathrm{KGF}$ on $\beta$-catenin, APC, GSK-3 $\beta$, axin, and LEF1 expression. KGF: keratinocyte growth factor; APC: adenomatous polyposis coli; GSK-3: glycogen synthase kinase-3 $\beta$; LEF1: lymphoid enhancer factor- 1 .

culture, DNA quantitation in $25 \mathrm{mmol} / \mathrm{L}$ group compared with $0 \mathrm{mmol} / \mathrm{L}$ group, $P<0.05$, as compared with other groups, $P>0.05$; after $72 \mathrm{~h}$ of culture, DNA quantitation in $25 \mathrm{mmol} / \mathrm{L}$ group compared with $0 \mathrm{mmol} / \mathrm{L}$ group, $P<$ 0.01 , as compared with other groups $P>0.05$; after $96 \mathrm{~h}$ of culture, DNA quantitation in $25 \mathrm{mmol} / \mathrm{L}$ group compared with $0 \mathrm{mmol} / \mathrm{L}$ group, $P<0.01$, as compared with other groups, $P<0.05$, also representing a significant difference; after $120 \mathrm{~h}$ of culture, DNA quantitation in $25 \mathrm{mmol} / \mathrm{L}$ group compared with $0 \mathrm{mmol} / \mathrm{L}$ group $P<0.05$, as compared with other groups $P>0.05$.

\section{Effect of KGF on HFSC proliferation}

The proliferation rate of HFSCs increased following KGF treatment, with a direct correlation between KGF dose and HFSC proliferation rate being observed [Figures 8 and 9]. HFSCs proliferated well at KGF concentrations less than $50 \mu \mathrm{g} /$. By contrast, at very high $\mathrm{KGF}$ concentrations HFSCs proliferated well at early time points, but died prematurely at later time points. At KGF concentrations of $10-25 \mu \mathrm{g} / \mathrm{L}$, cells proliferated well and showed no signs of premature aging at later time points.

Statistical analyses showed that after $24 \mathrm{~h}$ of culture, there were no significant differences between the KGF-dose 
treatment groups and the control group.

After $48 \mathrm{~h}$ of culture, the KGF $10 \mu \mathrm{g} / \mathrm{L}$ treatment group was significantly different as compared with the control group $(P<0.05)$, but there was no difference between the control group and the other KGF-dose treatment groups. After 72 $\mathrm{h}$ of culture, the KGF $10 \mu \mathrm{g} / \mathrm{L}$ treatment group showed a significant increase in proliferation when compared with the control group $(P<0.01)$. However, there was no observed difference between the control group and the other KGFdose treatment groups. After $96 \mathrm{~h}$ of culture, the 10, 25, and $100 \mu \mathrm{g} / \mathrm{L} \mathrm{KGF}$ treatment groups showed a significant increase in proliferation when compared with the control group $(P<$ $0.01)$. However, there was no significant difference between the control group and the $50 \mu \mathrm{g} / \mathrm{L}$ KGF treatment group. After $120 \mathrm{~h}$ of culture, all doses of KGF had significantly increased the proliferation of HFSCs compared with the control group $(P<0.05)$.

Effects of $\mathrm{LiCl}$ and $\mathrm{KGF}$ on HFSC differentiation and morphology.

There were obvious differences in cell morphodifferentiation, adhesion, and proliferation between the $10 \mathrm{mmol} / \mathrm{L} \mathrm{LiCl}$ and $10 \mu \mathrm{g} / \mathrm{L} \mathrm{KGF}$ treatment groups and the control group [Figure 10A-D]. The LiCl $10 \mu \mathrm{g} / \mathrm{L}$ treatment group showed a significant increase in proliferation [Figure $10 \mathrm{E}-\mathrm{H}]$. By contrast, the proliferation rate of KGF-treated cells initially increased in a dose-dependent manner. However, cell proliferation decreased with aging and vacuoles formed within the cells at later time points [Figure 10I-L].

Effects of $\mathrm{LiCl}$ and $\mathrm{KGF}$ on the mRNA expression of components of the $\mathrm{Wnt} / \beta$-catenin signaling pathway.

Following treatment with $10 \mathrm{mmol} / \mathrm{L} \mathrm{LiCl}$, the mRNA expression of $\beta$-catenin was increased when compared with control cells. There was also an increased expression of APC and LEF1 mRNA, but a gradual reduction in axin and GSK-3 $\beta$ mRNA expression [Figure 11].

Following treatment with $10 \mu \mathrm{g} / \mathrm{L} \mathrm{KGF}$, the expression of $\beta$-catenin mRNA did not change markedly compared with control cells; however, GSK-3 $\beta$ and LEF1 mRNA expression gradually declined [Figure 12].

\section{DISCUSSION}

HFSC differentiation is regulated by multiple factors, ${ }^{[1]}$ which interact to form an intricate regulatory system. ${ }^{[1,2]}$ The main intrinsic regulatory factors affecting HFSC proliferation and differentiation are $W n t, \beta$-catenin and the Notch and exit domain A (EDA) signaling pathways..$^{[1,10-12]}$ Extrinsic signals primarily include mitogens, intercellular interactions, cell growth factors [e.g. basic fibroblast growth factor (bFGF) and EGF], and some chemical substances (e.g. LiCl). ${ }^{[13-15]}$ These signals constitute the external microenvironment of proliferation and differentiation of HFSCs. KGF is a member of the FGF superfamily, which regulates the proliferation and differentiation of various cell types. KGF expression in matrix cells is sharply upregulated when skin is injured. ${ }^{[13]}$
KGF also facilitates HFSC proliferation. In this study, HFSCs were isolated from the hair follicle bulge and the effects of different concentrations of $\mathrm{LiCl}$ and KGF on HFSC proliferation and differentiation were explored.

LiCl, a crucial Wnt signaling agonist, inhibits the activity of GSK-3 $3 . .^{[11]}$ GSK-3 phosphorylation at serine-9 prevents GSK-3 $\beta$ from degrading $\beta$-catenin, thus elevating $\beta$-catenin expression. ${ }^{[14]}$ This study found that low $\mathrm{LiCl}$ concentrations $(0-10 \mathrm{mmol} / \mathrm{L})$ not only induce $\beta$-catenin expression but also slightly increase HFSCs proliferation. However, proliferation decreased as the $\mathrm{LiCl}$ concentration was increased. $\mathrm{LiCl}$ treatment also led to a reduction in cell adhesion and caused HFSCs to grow in dispersed clusters. This is a result of $\mathrm{LiCl}$ inhibiting intracellular E-cadherin expression, which weakens cell adhesion and facilitates cell migration. ${ }^{[15]}$ This phenomenon may result from E-cadherin transposition caused by $\beta$-catenin up-regulation. These data suggest that changes in $\beta$-catenin expression can change cell adhesion, which has an important role in promoting cell proliferation.

In the current study, $\beta$-catenin expression directly correlated with the $\beta$-catenin-axin-APC-GSK-3 $\beta$ complex, but inversely correlated with GSK-3 $\beta$ and axin levels. Axin, a critical negative regulator of the Wnt signaling pathway, is a key component of the $\beta$-catenin degradation complex. It has several protein-protein interaction domains and functions as scaffolding protein in various protein complexes. Axin brings GSK-3 $\beta$ in close proximity to $\beta$-catenin and regulates the degradation of phosphorylated $\beta$-catenin. This study demonstrated that $\mathrm{LiCl}$ suppresses the expression of GSK-3 $\beta$ mRNA and thus inhibits the formation of the axin complex, which indirectly elevates the level of $\beta$-catenin.

As a downstream transcription factor in the Wnt signaling pathway, LEF1activates the transcription of specific genes. According to recent reports, ${ }^{[7,8,16]}$ endogenous LEF1 synergizes with Wnt signaling. It is widely accepted that $\beta$-catenin activates downstream target genes through a complex formation with LEF1. Cofactor ALY, enhancer TCR $\alpha$, and LEF1 cooperatively form a higher-order nucleoprotein complex that enhances the synergistic activation of $\beta$-catenin/LEF1 and thus transcriptional activity. ${ }^{[16]}$ This study found that $\mathrm{LiCl}$ treatment increased the levels of $\beta$-catenin and LEF1 mRNA along with the course induce. It is likely that increased protein levels of $\beta$-catenin complex with LEF1. These results are identical with those of the abovementioned mechanisms of the Wnt signaling pathway, and indicate that activations of the $\beta$-catenin and LEF1 signaling pathways are involved in HFSC's differentiation.

Numerous studies have shown that $\beta$-catenin functions by forming a complex with LEF1 in the Wnt signaling pathway. ${ }^{[17-20]}$ Zhu et al. ${ }^{[17]}$ transfected keratinocytes with retrovirus and found that mutant LEF1 expressed in the basal lamina of transgenic mice cannot interact with $\beta$-catenin. Thus, hair formation is prevented and adult basal epidermal cells are transformed into pluripotent embryonic-like ectoderm. LEF1 is an essential transcriptional factor for the normal development of hair follicles. LEF1 expression stimulates the stem cell to develop into hair, facilitates differentiation of both hair matrix cells and hair 
follicles, and participates in the formation of the root sheath.

In an attempt to improve our understanding of the role of $\beta$-catenin in HFSC proliferation and differentiation, this study investigated whether KGF treatment stimulates these processes via the Wnt signaling pathway. The results indicate that adding KGF to serum-free culture medium containing EGF stimulated HFSC proliferation. Although this effect was not apparent in the first $48 \mathrm{~h}$ of culture, for incubation times more than $48 \mathrm{~h}$, there was a marked difference in DNA content between the 10 $\mu \mathrm{g} / \mathrm{L}$ KGF treatment group and control cells. The reduction in DNA content indicates that KGF maintains cell proliferation and postpones keratinocyte differentiation.

Richardson et al.$^{[6]}$ observed repression of hair follicle induction by KGF and EGF in cultured mice embryo skin. They found that Wnt signaling plays a role in the initial formation of hair follicles, and that the latter stages of follicle formation are dependent on the Shh signal. Formation of the hair follicle is usually caused by activation of Wnt signaling and upregulation of $\beta$-catenin mRNA. The Shh activating signal also elevates Gli1 mRNA. Nuclear LEF1 expression occurs at the initial stages and increases after $24 \mathrm{~h}$. However, epidermal cells induced by KGF or EGF contain high nuclear LEF1 expression at all time points. KGF and EGF noticeably inhibited several important signaling molecules produced by hair follicles, including Wnt (LEF1, DKK4), Shh single pathway, and delayed HFSC differentiation. Recently, Andreadis et al. ${ }^{[21]}$ using a skin equivalent model system, demonstrated that KGF significantly facilitates the proliferation of epidermal cells inoculated in a cellular dermal matrix, which is associated with induced expression of $\alpha 5 \beta 1$ integrins and delayed keratin-10 expression. In the present study, HFSCs were observed to exhibit a low proliferation rate in the first $72 \mathrm{~h}$ after KGF treatment, especially in the $10 \mu \mathrm{g} / \mathrm{L}$ treatment group. When the culture time was longer than $72 \mathrm{~h}$, DNA measurements showed that KGF treatment postponed apoptosis, but that high KGF concentrations accelerated cell aging. This may be related to excessive nutrient consumption in the in vitro culture medium. In cells treated with $10 \mu \mathrm{g} / \mathrm{L} \mathrm{KGF} \beta$-catenin expression increased slightly and GSK-3 $\beta$ expression decreased on day 7 , as HFSCs underwent differentiation. LEF1 levels, however, declined at an early stage. How KGF switches the Wnt/ $\beta$-catenin pathway from an activated state to an inhibited state is unclear. However, this data suggest that KGF concentration inversely correlates with LEF1 expression and represses HFSC differentiation and the formation of hair follicles. This result supports a direct association of KGF with the Wnt signaling pathway through reducing LEF1 levels. These data are consistent with the results of Richardson et al. ${ }^{[6]}$ However, some of the links that mediate KGF regulation of the Wnt signaling pathway are not yet clear and require further investigation.

\section{Financial support and sponsorship}

This study is supported by the National Natural Science Foundation of China (No.30772099) and Beijing Municipal Natural Science Foundation (No.7112111).

\section{Conflicts of interest}

There are no conflicts of interest.

\section{REFERENCES}

I. Yang B, Xiang MJ. Regulation of Wnt signaling pathway involved in the differentiation of hair follicle stem cells induced by lithium chloride. Zhongguo Zuzhi Gongcheng Yanjiu yu Linchuang Kangfu 20I I; I 5:9202-6.

2. Taylor G, Lehrer MS, Jensen PJ, Sun TT, Lavker RM. Involvement of follicular stem cells in forming not only the follicle but also the epidermise. Cell 2000; I02:45I-6I.

3. Waikel RL, Kawachi Y,Waikel PA, Wang XJ, Roop DR. Deregulated expression of c-Myc depletes epidermal stem cells. Nat Genet 200।;28:165- 8.

4. DasGupta R, Kaykas A, Moon RT, Perrimon N. Functional genomic analysis of the Wnt-wingless signaling pathway. Science 2005;308:826-33.

5. Michel M, Török N, Godbout MJ, Lussier M, Gaudreau P, Royal A, Germain L. Keratin 19 as a biochemical marker of skin stem cells in vivo and in vitro: keratin 19 expressing cells are differentially localized in function of anatomic sites, and their number varies with donor age and culture stage.J Cell Sci 1996; 109:1017-28.

6. Richardson GD, Bazzi H, Fantauzzo KA, Waters JM, Crawford H, Hynd P, Christiano AM, Jahoda CA. KGF and EGF signalling block hair follicle induction and promote interfollicular epidermal fate in developing mouse skin. Development 2009; 136:2153-64

7. Mullis KB, Faloona FA. Specific synthesis of DNA in vitro via a polymerasecatalyzed chain reaction. Methods Enzymol 1987; 155:335-50.

8. Watt FM. Epidermal stem cells: markers, patterning and the control of stem cell fate. Philos Trans R Soc Lond B Biol Sci 1998;353:831-7.

9. Commo S, Gaillard O, Bernard BA. The human hair follicle contains two distinct KI9 positive compartments in the outer root sheath: a unifying hypothesis for stem cell reservoir. Differentiation 2000;66:157-64.

10. Widelitz RB.Wnt signaling in skin organogenesis. Organogenesis 2008;4:123-3.

II. Lapébie P, Gazave E, Ereskovsky A, Derelle R, Bézac C, Renard E, Houliston $E$, Borchiellini $C$. Wnt/ $\beta$-catenin signaling and epithelial patterning in the homoscleromorph sponge oscarella. PLoS One 2009;4:1-6.

12. Lowell S, Jones P, Le Roux I, Dunne J, Watt FM. Stimulation of human epidermal differentiation by delta-notch signaling at the boundaries of stemcell clusters. Curr Biol 2000; 10:491-500

13. Marchese C, Chedid M, Dirsch OR, Csaky KG, Santanelli F, Latini C, LaRochelle WJ, Torrisi MR, Aaronson SA. Modulation of keratinocyte growth factor and its receptor in reepithelializing human skin.J Exp Med 1995;182:1369-76.

14. Wexler EM, Geschwind DH, Palmer TD. Lithium regulates adult hippocampal progenitor development through canonical Wnt pathway activation. Mol Psychiatry 2008; 13:285-92.

15. Rao AS, Kremenevskaja N, Resch J, Brabant G. Lithium stimulates proliferation in cultured thyroeytes by activating Wnt/beta-catenin signalling. Eur J Endocrinal 2005; I53:929-38.

16. Hsu SC, Galceran J, Grosschedl R. Modulation of transcriptional regulation by LEF-I in response to Wnt-I signaling and association with beta-Catenin Mol Cell Biol 1998;18:4807-I8.

17. Zhu AJ, Watt FM. Beta-catenin signaling modulates proliferative potential of human epidermal keratinocytes independently of intercellular adhesion. Development 1999;।26:2285-98.

18. DasGupta R, Rhee H, Fuchs E. A developmental conundrum: astabilized form of beta - catenin lacking the transcriptional activation domain triggers features of hair cell fate in epidermal cells and epidermal cell fate in hair follicle cells. J Cell Biol 2002; 158:33 I-44.

19. Nguyen H, RendI M, Fuchs E.Tcf3 governs stem cell features and represses cell fate determination in skin. Cell 2006;10:171-83.

20. Fathke C,Wilson L, Shah K, Kim B, Hocking A, Moon R, Isik F.Wnt signaling induces epithelial differentiation during cutaneous wound healing. BMC Cell Biol 2006;7:4.

21. Andreadis ST, Hamoen KE, Yarmush ML, Morgan JR. Keratinocyte growth factor induces hyperproliferation and delays differentiation in a skin equivalent model system. FASEB J 200I;15:898-906. 